\title{
THE PATENTABILITY OF BLOCK CHAIN TECHNOLOGY AND THE FUTURE OF INNOVATION
}

\author{
Tri Destanto \\ 175100067P, 785567961 \\ Fakultas Komputer \\ tridestanto@umitra.ac.id
}

\begin{abstract}
In the United States, Alice Corp. Pty. Ltd. v. CLS Bank International is frequently cited for issues dealing with software patents. Alice was a 2014 case decided by the Supreme Court about patentable subject matter. The patent at issue in Alice was a computer-implemented scheme for mitigating settlement risk. In its decision, referencing 35 U.S.C. $§ 101$, the Court explained that it has "long held that this provision contains an important implicit exception: Laws of nature, natural phenomena, and abstract ideas are not patentable" because they are "the basic tools of scientific and technological work," and "“[m] onopolization of those tools through the grant of a patent might tend to impede innovation more than it would tend to promote it,' thereby thwarting the primary object of the patent laws."

For example, in Gottschalk v. Benson, the Court rejected as ineligible, patent claims involving an algorithm for converting binary-coded decimal numerals into pure binary form, holding that the claimed patent was "in practical effect . . . a patent on the algorithm itself." Similarly, in Parker v. Flook, the Court held that a mathematical formula for computing "alarm limits" in a catalytic conversion process was also a patent-ineligible abstract idea. More recently, the Court in Bilski v. Kappos held that the patent at issue (the basic concept of hedging, or protecting against risk) is an "abstract idea" because "[h]edging is a fundamental economic practice long prevalent in our system of commerce and taught in any introductory finance class."
\end{abstract}

Key Word : Patent, Information Technology, Innovation 


\section{A. INTRODUCTION}

In November 2008, Bitcoin's creator, known by the pseudonym Satoshi Nakamoto, published a paper via the Cryptography Mailing List titled "Bitcoin: A Peer-to-Peer Electronic Cash System." In it, he describes blockchain as "[a] purely peer-to-peer version of electronic cash [that] would allow online payments to be sent directly from one party to another without going through a financial institution." He spends the rest of the paper elaborating on this "system for electronic transactions."Among the eight references cited in the paper, the oldest dates back to 1957 and references algorithms.

Essentially, blockchain was originally created to facilitate transaction of the digital currency Bitcoin, but since has been used for other technological applications. When someone requests a transaction using blockchain technology, it is broadcast to a peer-topeer network consisting of computers, known as nodes, which employs algorithms to validate the transaction and the user's status. Once the transaction has been verified, it is combined with other transactions to create a new block of data for the ledger that is then added to the existing blockchain, and the transaction is considered complete.

Given the way blockchain technology works, getting a patent on it is akin to getting a software patent based on an abstract idea/algorithm because the functioning of the technology is based on a series of steps performed. In the United States, § 101 of the Patent Act defines the subject matter eligible for patent protection: "Whoever invents or discovers any new and useful process, machine, manufacture, or composition of matter, or any new and useful improvement thereof, may obtain a patent therefor, subject to the conditions and requirements of this title."

As for case law pertinent to what is considered patentable subject matter, in Mayo Collaborative Services v. Prometheus Laboratories, Inc., the US Supreme Court devised a method for distinguishing patents that are patentable and those that are not. The first step is to determine whether the patent claims laws of nature, natural phenomena, or abstract ideas, or patent-eligible applications of those concepts. And the second step is to determine whether the additional elements of the patent application "transform the nature of the claim" into a patent-eligible application. This second step is more commonly known as the "inventive concept," i.e., an element or combination of elements that is "sufficient to ensure that the patent in practice amounts to significantly more than a patent upon the [ineligible concept] itself." 


\section{B. CONTENT}

\section{Novelty And Nonobviousness}

Even if an application claims patentable subject matter, to get a patent, the patentee still needs to show novelty and nonobviousness under $\S \S 102$ and 103, respectively, of the United States Patent Act. Both novelty and nonobviousness are determined at the date of invention. But the principal difference between the two is that while novelty requires a single piece of prior art with all the limitations, nonobviousness can use combinations of prior art. Therefore, even if these patent applications pending in the United States pass muster as being patent eligible, they will still have a hard time passing the novelty and nonobviousness requirementsespecially because novelty means that if the patent application was filed after the America Invents Act went into effect on March 17, 2013, the inventor has to show that the claimed invention was not patented, described in a printed publication, or in public use, on sale, or otherwise available to the public anywhere in the world before the effective filing date of the claimed invention. If the patent application was filed before March 17, 2013, the inventor has to show that the claimed invention was not known or used in the United States by others before the date of invention, patented by others anywhere in the world before the date of invention, published by others anywhere before the date of invention, patented or published by anyone anywhere one year before the filing date, or in public use or on sale by anyone in the United States one year before the filing date.

This means that even if a specific blockchain technology can be patented based on 35 U.S.C. $§ 101$ as a "process," it still needs to show that the claims in the patent application are novel and nonobvious. All of these requirements can certainly be hard to show given the proliferation of blockchain technology and the fact that it has recently been applied to so many uses other than digital currency. For example, blockchain technology has been used in the fashion industry, Nonetheless, a few blockchain patents have already been granted. For example, Goldman Sachs has been awarded a patent for its proposed SETLcoin cryptocurrency settlement system, which envisions a system for settling securities trades using a builtin cryptocurrency.

\section{Patentability Across The Pond}

Comparatively, in the United Kingdom, there are four overriding requirements in order for a patent to be granted: there must be an invention, which must be novel, inventive, and capable of industrial application. While patent laws in the United Kingdom specify a nonexhaustive list of things not considered inventions that includes programs for computers, the United Kingdom Intellectual Property Office (UKIPO) has been known to grant patents to inventions that are partly or wholly implemented in software. For example, in 2008, the UK Court of Appeal refused to accept the UKIPO's rejection of a patent for a piece of 
software. In the case, Symbian won the right to patent a piece of software that makes other software run more quickly. Specifically, the court stated that because Symbian's software produced an effect on other pieces of technology, it was patent eligible. Similar to US law though, the UK Patents Act does not allow patents for a mathematical method. It also does not allow patents for inventions whose commercial exploitation would be contrary to public policy or morality. The United Kingdom's novelty requirement is very similar to the United States'.

Similar to the US Patent Act and the UK Patents Act, the Canadian Patent Act defines an invention as "any new and useful art, process, machine, manufacture or composition of matter." Most notably, in Canada (Attorney General) v. Amazon.com, Inc., the Canada Federal Court of Appeal explained that software and business methods are not excluded from patentability, and held that an invention will be patentable if it has physical existence or if there is something that manifests a discernible effect or change. Thus, applications for blockchain technology patents pending in the United Kingdom and Canada should face some of the same problems they would face if filed in the United States.

\section{Blockchain Patents And Innovation}

The most notable patent filers in the blockchain technology space have been banks. Besides Goldman Sachs, Bank of America and Mastercard have also been aiming to patent some of the most promising blockchain technologies for themselves. Allegedly, the proliferation in the number of blockchain and cryptocurrency patents filed is a protective measure. For example, Mastercard's Justin Pinkham has been credited with saying that "like many other companies, [Mastercard] is simply filing patents to defend its blockchain inventions - as it always does, in all areas of its work." He explained, "We have expanded our patent portfolio to protect the company's thinking, innovations and intellectual property." However, this behavior, though warranted, is problematic for the reasons laid out below.

First, patenting blockchain technology means less interoperability for organizations. Less interoperability in turn means less innovation. In fact, software patents that cover abstract ideas are becoming harder to obtain since the Alice ruling. Open source software development is a way of life for some developers. In fact, the World Wide Web as we know it today was largely created because of open source software development with Tim Berners-Lee contributing his HTML code development as the original platform upon which the Internet is now built. As the technology is used and understood today, blockchain can be compared to the open source protocol-Transmission Control Protocol and Internet Protocol (TCP/IP) - from the early days of the Internet. This is because for several years after TCP/IP was created, only a few people had access to the technology. Similarly, the blockchain technology algorithm is too obscure 
for most people to understand in depth the way in which it works. And, this recent proliferation of filing for blockchain patents is likely to exclude several organizations and/or individuals who do understand it well enough from reverse engineering and using the technology in innovative ways without obtaining costly licenses. I can conceive of several important uses for blockchain technology in the future. As just one example, in health care, there are often different electronic medical records systems used, each with its own language for representing and sharing patient data. Blockchain can revolutionize this process and the way in which recordkeeping systems are used in general. However, as more organizations obtain blockchain patents, it will get harder for nonassignees to implement ideas that use blockchain to revolutionize conventional industry practice, which is the idea emphasized by the Court in Diehr.

This brings me to my second point: part of the problem is patent trolls. Without the fear of patent trolls, the firms currently racing to obtain patents would not have ways to protect their “company's thinking, innovations and intellectual property" by obtaining patents at the forefront of the company's overall strategy. After all, the objective of Article I, Section 8, Clause 8 of the United States Constitution is to promote the progress of science and the useful arts. Like the Mayo Court emphasized, obtaining patents should be more than a drafting effort designed to monopolize the abstract idea. When granted, these blockchain patents may harm innovation, collaboration, and interoperability by bringing an open source technology into the world of patents. In fact, before Alice was decided in 2014, the Electronic Frontier Foundation in 2013 posted a blog on its website about the rise of patent trolls with the rise in software patents. With respect to blockchain technology, companies like R3CEV, the start-up behind the world's largest banking consortium focused on distributed ledger applications, has released code for its Corda platform freely available to all. Obviously, the more code related to blockchain technology that is made open source, the more the potential for patent applications filed to be rejected based on the novelty requirement laid out in 35 U.S.C. § 102. And like mentioned before, making blockchain technology open source will incentivize people to invest their time and energy in understanding the technology and innovating to revolutionize conventional industry practice, thereby accomplishing the United States Constitution's Article I, Section 8, Clause 8 goal. 


\section{CONCLUSION}

The number of patent applications being filed for blockchain technology is on the rise. However, getting a patent on blockchain technology that uses a peer-to-peer network using proof-of-work to record a public history of transactions is like getting a patent on an algorithm, is directed to an abstract idea, and is likely going to fail the first step of the Mayo test under US law. Nonetheless, if the patented invention uses the algorithm in a process designed to solve a technological problem in "conventional industry practice," the assignee could get the patent. But even if a specific blockchain technology is considered to be patentable subject matter, the claims in the patent application must still be shown to be novel and nonobvious. Recently, some banks have been granted patents on their own version of blockchain technology. Moving forward though, it may be harder to get such patents given that organizations like R3CEV and Chain plan to make their blockchain software code open to the public, thus making it harder for a patentee to show its invention meets the definition of novel and nonobvious.

\section{DISCUSSION}

Given the way blockchain technology works, getting a patent on it is akin to getting a software patent based on an abstract idea/algorithm because the functioning of the technology is based on a series of steps performed. In the United States, § 101 of the Patent Act defines the subject matter eligible for patent protection: "Whoever invents or discovers any new and useful process, machine, manufacture, or composition of matter, or any new and useful improvement thereof, may obtain a patent therefor, subject to the conditions and requirements of this title."

As for case law pertinent to what is considered patentable subject matter, in Mayo Collaborative Services v. Prometheus Laboratories, Inc., the US Supreme Court devised a method for distinguishing patents that are patentable and those that are not.

The first step is to determine whether the patent claims laws of nature, natural phenomena, or abstract ideas, or patent-eligible applications of those concepts. And the second step is to determine whether the additional elements of the patent application "transform the nature of the claim" into a patent-eligible application. This second step is more commonly known as the "inventive concept," i.e., an element or combination of elements that is "sufficient to ensure that the patent in practice amounts to significantly more than a patent upon the [ineligible concept] itself." 


\section{E. REFERENCE}

[1] O. M. Febriani and A. S. Putra, "Sistem Informasi Monitoring Inventori Barang Pada Balai Riset Standardisasi Industri Bandar Lampung," J. Inform., vol. 13, no. 1, pp. 90-98, 2014.

[2] A. S. Putra, "Paperplain: Execution Fundamental Create Application With Borland Delphi 7.0 University Of Mitra Indonesia," 2018.

[3] A. S. Putra, "2018 Artikel Struktur Data, Audit Dan Jaringan Komputer," 2018.

[4] A. S. Putra, "ALIAS MANAGER USED IN DATABASE DESKTOP STUDI CASE DB DEMOS."

A. S. Putra, "COMPREHENSIVE SET OF PROFESSIONAL FOR DISTRIBUTE COMPUTING."

[6] A. S. Putra, "DATA ORIENTED RECOGNITION IN BORLAND DELPHI 7.0."

[7] A. S. Putra, "EMBARCADERO DELPHI XE 2 IN GPUPOWERED FIREMONKEY APPLICATION."

[8] A. S. Putra, "HAK ATAS KEKAYAAN INTELEKTUAL DALAM DUNIA TEKNOLOGY BERBASIS REVOLUSI INDUSTRI 4.0."

[9] A. S. Putra, "IMPLEMENTASI PERATURAN PERUNDANGAN UU. NO 31 TAHUN $2000 \quad$ TENTANG DESAIN INDUSTRI BERBASIS INFORMATION TECHNOLOGY."

[10] A.

S. Putra,
"IMPLEMENTATION OF PARADOX DBASE."

[11]

$\begin{array}{lrr}\text { A. } & \text { S. } & \text { Putra, } \\ \text { "IMPLEMENTATION } & \text { OF } \\ \text { TRADE } & \text { SECRET } & \text { CASE } \\ \text { STUDY } & \text { SAMSUNG } \\ \text { PHOBE." }\end{array}$

A. S. Putra, "IMPLEMENTATION

PATENT FOR APPLICATION WEB BASED CASE STUDI WWW. PUBLIKLAMPUNG. COM."

[13] A. S. Putra, "IMPLEMENTATION SYSTEM FIRST TO INVENT IN DIGITALLY INDUSTRY."

[14] A. S. Putra, "MANUAL REPORT \& INTEGRATED DEVELOPMENT

ENVIRONMENT BORLAND DELPHI 7.0."

[15] A. S. Putra, "PATENT AS RELEVAN SUPPORT RESEARCH."

[16] A. S. Putra, "PATENT FOR RESEARCH STUDY CASE OF APPLE. Inc."

[17] A. S. Putra, "PATENT PROTECTION FOR APPLICATION INVENT."

[18] A. S. Putra, "QUICK REPORT IN PROPERTY PROGRAMMING."

[19] A. S. Putra, "REVIEW CIRCUIT LAYOUT COMPONENT

REQUIREMENT ON ASUS NOTEBOOK."

[20] A. S. Putra, "REVIEW TRADEMARK PATENT FOR INDUSTRIAL TECHNOLOGY BASED 4.0."

[21] A. S. Putra, "TOOLBAR COMPONENT PALLETTE IN 
OBJECT

ORIENTED

PROGRAMMING."

[22] A. S. Putra, "WORKING DIRECTORY SET FOR PARADOX 7."

[23] A. S. Putra, "ZQUERY CONNECTION

IMPLEMENTED

PROGRAMMING

STUDI

CASE PT. BANK BCA Tbk."

[24] A. S. Putra, D. R. Aryanti, and I. Hartati, "Metode SAW (Simple Additive Weighting) sebagai Sistem Pendukung Keputusan Guru Berprestasi (Studi Kasus: SMK Global Surya)," in Prosiding Seminar Nasional Darmajaya, 2018, vol. 1, no. 1, pp. 85-97.

[25] A. S. Putra and O. M. Febriani, "Knowledge Management Online Application in PDAM Lampung Province," in Prosiding International conference on Information Technology and Business (ICITB), 2018, pp. 181-187.

[26] A. S. Putra, O. M. Febriani, and B. Bachry, "Implementasi Genetic Fuzzy System Untuk Mengidentifikasi Hasil Curian Kendaraan Bermotor Di Polda Lampung," SIMADA (Jurnal Sist. Inf. dan Manaj. Basis Data), vol. 1, no. 1, pp. 21-30, 2018.

[27] A. S. Putra, H. Sukri, and K. Zuhri, "Sistem Monitoring Realtime Jaringan Irigasi Desa (JIDES) Dengan Konsep Jaringan Sensor Nirkabel," IJEIS (Indonesian J. Electron. Instrum. Syst., vol. 8, no. 2, pp. 221-232.

[28] D. P. Sari, O. M. Febriani, and
A. S. Putra, "Perancangan Sistem Informasi SDM Berprestasi pada SD Global Surya," in Prosiding Seminar Nasional Darmajaya, 2018, vol. 1, no. 1, pp. 289-294. 